\title{
Quantifying and Validating Soybean Seed Emergence Model as a Function of Temperature
}

\author{
Firas Ahmed Alsajri'1, Chathurika Wijewardana', L. Jason Krutz², J. Trenton Irby', \\ Bobby Golden ${ }^{3}$, K. Raja Reddy ${ }^{{ }^{*}}$
}

\author{
${ }^{1}$ Department of Plant and Soil Sciences, Mississippi State University, Mississippi State, MS, USA \\ ${ }^{2}$ Mississippi Water Resources Research Institute, Mississippi State University, Mississippi State, MS, USA \\ ${ }^{3}$ Delta Research and Extension Center, Stoneville, MS, USA \\ Email: *krreddy@pss.msstate.edu
}

How to cite this paper: Alsajri, F.A., Wijewardana, C., Krutz, L.J., Irby, J.T., Golden, B. and Reddy, K.R. (2019) Quantifying and Validating Soybean Seed Emergence Model as a Function of Temperature. American Journal of Plant Sciences, 10, 111-124.

https://doi.org/10.4236/ajps.2019.101010

Received: December 20, 2018

Accepted: January 15, 2019

Published: January 18, 2019

Copyright $\odot 2019$ by author(s) and Scientific Research Publishing Inc. This work is licensed under the Creative Commons Attribution International License (CC BY 4.0).

http://creativecommons.org/licenses/by/4.0/

\begin{abstract}
Developing a model for soybean seed emergence offers a tool producers could use for planting date options and in predicting seedling emergence. In this study, temperature effects on soybean seed emergence were quantified, modeled, and validated. The data for seed emergence model development was generated at varying temperatures, $20^{\circ} \mathrm{C} / 12^{\circ} \mathrm{C}, 25^{\circ} \mathrm{C} / 17^{\circ} \mathrm{C}, 30^{\circ} \mathrm{C} / 22^{\circ} \mathrm{C}$, $35^{\circ} \mathrm{C} / 27^{\circ} \mathrm{C}$, and $40^{\circ} \mathrm{C} / 32^{\circ} \mathrm{C}$, on two soybean cultivars, Asgrow AG5332 and Progeny P 5333 RY. Time for $50 \%$ emergence ( $\mathrm{t} 50 \%$ ) was recorded, and seed emergence rate (SER) was estimated as reciprocal to time at each temperature in both the cultivars. No differences were observed between the cultivars in their response to temperature. A quadratic model (QM) best described the relationship between t50\% and SGR and temperature $\left(R^{2}=0.93\right)$. Two sets of experiments were conducted to validate the model. In Experiment 1, 17 time-series planting date studies with the same cultivars were used by utilizing diurnal and seasonal changes in temperature conditions. In the second experiment, sunlit growth chambers with 3 different day/night temperatures, low $-20^{\circ} \mathrm{C} / 12^{\circ} \mathrm{C}$, optimum $-30^{\circ} \mathrm{C} / 22^{\circ} \mathrm{C}$, and high $-40^{\circ} \mathrm{C} / 32^{\circ} \mathrm{C}$, and 64 soybean cultivars belonging MG III, IV, and V, were used. Air temperature and t50 were recorded, and SGR was estimated in all experiments. No differences were recorded among the cultivars for t50\% and SGR, but differences were observed among seeding date and temperature experiments. We tested QM and traditionally used Growing Degree Days models against the data collected in validation experiments. Both the model simulations predictions agreed closely with the observed data. Based on model statistics, $\mathrm{R}^{2}$, root mean square errors (RMSE), and comparison of observations and predictions
\end{abstract}


to assess model performance, the QM model performed better than the GDD model for soybean seed emergence under a wide range of cultivars and environmental conditions.

\section{Keywords}

Growing Degree Days Model, Seed Emergence, Soybean, Temperature

\section{Introduction}

Soybean (Glycine max [L.] Merr) seed germination and emergence are important components of the crops cycle as uniform stand establishment have been documented to have a positive correlation with in-season crop growth and development and final yield [1]-[8]. Seed emergence is, therefore, a critical stage that ends with dependence on stored reserves and starts an autotrophic life with the production of chloroplast in the developing organs aboveground. Many field applications have widely used soybean phenology staging system developed by Fehr et al. [9]. This system defined soybean emergence when cotyledons unfold and appear above the soil surface. The timing of emergence frequently determines whether a single plant competes successfully with its neighbors and other predators and weeds. With many significant plant processes and management at stake, a full understanding and documenting of seed emergence process seems necessary. Surprisingly, soybean emergence has not been fully addressed, particularly in many recent cultivars even though some work has been carried in earlier cultivars [10] [11] [12].

Several environmental factors, temperature, soil moisture, and soil physical characteristics, and seed quality traits influence seed emergence in plants [13]. Among the abiotic stress factors, temperature plays a dominant role in controlling growth and developmental rates of plants under optimum water and nutrient conditions including seed germination and emergence. There are major differences among plant species in their sensitivities to temperature. Even cultivars or hybrids vary in their sensitivity to temperature [14] [15]. In a crop production system, temperature varies spatially and temporally over the growing season. Each crop event or individual developmental aspect has a specific temperature optimum, and above that optimum, plant development will be declined. The mechanisms and sensitivities of this process to environmental stimuli vary among plant processes and sometimes among cultivars.

Castiel [16] proposed Growing Degree Days Model (GDD) in predicting soybean seed emergence with a base temperature of $50^{\circ} \mathrm{F}\left(10^{\circ} \mathrm{C}\right)$ and the growing degree days required for seed emergence to be 90 from $50^{\circ} \mathrm{F}$ (32.22 GDD's from $10^{\circ} \mathrm{C}$ ). The base temperature varies among various developmental rates within a plant species [17] and for a given developmental time among plant species [18] because of its simplicity, GDD models were used to predict crop developmental rates. However, many of the crop developmental rates are not always respond to 
temperature linearly, other models such as quadratic models (QM) [18] [19] have been introduced in describing crop developmental responses to temperature. The merit of using a QM in predicting crop developmental rates eliminates some of the issues related to the methods of calculation of GDD as described by McMaster and Wilhelm [20].

In soybean, Hatfield and Egli [11] showed that time to reach 5-mm hypocotyl length decreased with temperature from $10^{\circ} \mathrm{C}$ to $32^{\circ} \mathrm{C}$ and then increased $33^{\circ} \mathrm{C}$ to $40^{\circ} \mathrm{C}$. They also stated that the radicle did not emerge from seed coat at $40^{\circ} \mathrm{C}$. Functional relationships between temperature and seed emergence on improved cultivars of soybean that are currently grown are limited to develop a model. The objectives of this study were to determine temperature effects on seed emergence response of modern soybean cultivars, develop a temperature-dependent seed emergence model, and validate the model from the data collected across a wide range of environmental conditions, planting dates, and cultivars.

\section{Material and Methods}

\subsection{Database for Modeling Experiment}

\subsubsection{Experimental Facilities}

An experiment was conducted using sunlit plant growth chambers known as Soil-Plant-Atmosphere-Research (SPAR) units located at the Rodney Foil Plant Science Research Center, Mississippi State University, Mississippi State, MS, in 2014. Five SPAR units were used in this experiment. The SPAR units can precisely control air temperatures and chamber carbon dioxide concentration at predetermined set points at near ambient levels of solar radiation. Each SPAR unit consists of a steel soil bin with $1 \mathrm{~m}$ deep by $2 \mathrm{~m}$ long and $0.5 \mathrm{~m}$ wide that houses either rooting medium or pots and a Plexiglas chamber with $2.5 \mathrm{~m}$ tall by $2 \mathrm{~m}$ long $\times 1.5 \mathrm{~m}$ wide that houses aerial plant system. The Plexiglas chamber is connected to a heating and cooling system and fan connected to air ducts that pass conditioned air through the plant canopy at the rate to simulate the field-level leaf flutter. The environmental monitoring and control systems are supporting the SPAR units by a network to store the data and provide automatic acquisition of data at $10 \mathrm{~s}$ intervals throughout the day and night. More details about the operations and controls of SPAR chambers have been described by Reddy et al. [21]. During the experiment, the daily solar radiation from 285 $2800 \mathrm{~nm}$, outside the SPAR units, was recorded using pyranometer (Model 4-8; The Eppley Laboratory Inc., Newport, RI) and ranged from 17 to $28 \mathrm{MJ} \cdot \mathrm{m}^{-2} \cdot \mathrm{d}^{-1}$ with an average of $21 \mathrm{MJ} \cdot \mathrm{m}^{-2} \cdot \mathrm{d}^{-1}$ (Table 1). To eliminate the need for border plants, variable density shade cloths that were designed to simulate canopy spectral properties placed around the edges of the plant canopy were raised regularly to reach canopy height.

In the returning path of airline ducts, a humidity and temperature sensor (HMV 70Y, Vaisala Inc., San Jose, CA) was installed to monitor the relative humidity (RH) of each chamber, From these measurements, the vapor pressure deficits (VPD) in the units were estimated as per Murray [22] (Table 1). For the 
Table 1. The set of Temperature treatments, average day, night, and day/night temperature, the mean of daily measured chamber $\mathrm{CO}_{2}$ concentration, and vapor pressure deficit (VPD) during the experimental period, 11 days after planting and treatments, for various temperature treatments conducted in the Soil-Plant-Atmosphere-Research units located at Mississippi State, MS.

\begin{tabular}{cccccc}
\hline $\begin{array}{c}\text { Day/night } \\
\text { temperature } \\
\text { treatments, }{ }^{\circ} \mathrm{C}\end{array}$ & Day & Night & Day/night & $\begin{array}{c}\mathrm{CO}_{2} \\
\text { Toncentration, } \\
\mu \text { mol mol }^{-1}\end{array}$ & $\begin{array}{c}\text { Mean daily } \\
\text { VPD, kPa }\end{array}$ \\
\cline { 2 - 6 } $20 / 12$ & $20.21 \dagger \mathrm{e}$ & $12.65 \mathrm{e}$ & $16.94 \mathrm{e}$ & $419 \mathrm{a}$ & $0.55 \mathrm{e}$ \\
$25 / 17$ & $25.05 \mathrm{~d}$ & $17.20 \mathrm{~d}$ & $21.64 \mathrm{~d}$ & $419 \mathrm{a}$ & $1.19 \mathrm{~d}$ \\
$30 / 22$ & $29.28 \mathrm{c}$ & $21.64 \mathrm{c}$ & $25.97 \mathrm{c}$ & $420 \mathrm{a}$ & $1.49 \mathrm{c}$ \\
$35 / 27$ & $34.15 \mathrm{~b}$ & $26.52 \mathrm{~b}$ & $30.83 \mathrm{~b}$ & $421 \mathrm{a}$ & $2.67 \mathrm{~b}$ \\
$40 / 32$ & $38.67 \mathrm{a}$ & $31.03 \mathrm{a}$ & $35.36 \mathrm{a}$ & $421 \mathrm{a}$ & $3.68 \mathrm{a}$ \\
\hline
\end{tabular}

$\dagger$ Values in each column followed by the same letter are not significantly different $(P \leq 0.05)$ according to Fisher's LSD.

duration of the treatment period, evapotranspiration rats (ET) was monitored and expressed on a ground area basis $\left(\mathrm{L} \cdot \mathrm{d}^{-1}\right)$ for each SPAR unit. The ET was calculated as the rate at which condensate was removed by the cooling coils at $900 \mathrm{~s}$ intervals by measuring the volume of water in collecting devices connected to a calibrated pressure transducer (Table $1 ;[23]$ ).

\subsubsection{Plant Materials and Temperature Treatments}

Two soybean cultivars, Asgrow AG 5332 (AG) with indeterminate and Progeny P5333 RY (PR) with determinate growth habits, from Maturity Group V were used for this experiment. Four seed were planted in 90 PVC (polyvinyl chloride) plastic pots $(15.2 \mathrm{~cm}$ diameter and $30.5 \mathrm{~cm}$ height) at $1.5-2 \mathrm{~cm}$ soil depth. Pots were filled with topsoil: sand (1:3 by volume) medium classified as a sandy loam ( $87 \%$ sand, $2 \%$ clay, and $11 \%$ silt) with $0.5 \mathrm{~kg}$ gravel at the bottom. Each pot had a hole $(0.5 \mathrm{~cm}$ diameter) at the bottom to allow the drainage of extra water and nutrients. The plants were irrigated and fertilized with full-strength Hoagland nutrient solution [24] by an automated drip irrigation system delivered three times a day at 0700,1200 , and $1700 \mathrm{~h}$. Each SPAR was assigned to 1 temperature treatment, 18 pots, nine pots for each cultivar, arranged in six rows, three pots per row in a completely randomized design with a $5 \times 2$ factorial arrangement.

Five day/night temperature treatments, $20^{\circ} \mathrm{C} / 12^{\circ} \mathrm{C}, 25^{\circ} \mathrm{C} / 17^{\circ} \mathrm{C}, 30^{\circ} \mathrm{C} / 22^{\circ} \mathrm{C}$, $35^{\circ} \mathrm{C} / 27^{\circ} \mathrm{C}$, and $40^{\circ} \mathrm{C} / 32^{\circ} \mathrm{C}$, imposed from seeding were maintained within $\pm 0.5^{\circ} \mathrm{C}$ of the treatment set points measured with aspirated thermocouples (Table 1). The daytime temperature was initiated at sunrise and returned to the nighttime temperature one $\mathrm{h}$ after sunset. The chamber $\left[\mathrm{CO}_{2}\right]$ was measured and maintained at $420 \mu \mathrm{mol} \cdot \mathrm{mol}^{-1}$ with a dedicated infrared gas analyzer (LI-COR, Model LI-6552, Lincoln, NE) from a gas sample that was drawn through the lines underground from each SPAR unit to the inside the laboratory. Pure $\mathrm{CO}_{2}$ was supplied from a compressed gas cylinder through a system that included a pressure regulator, solenoid and needle valves and a calibrated flow meter to 
maintain chamber $\left[\mathrm{CO}_{2}\right]$ at desired set points [20]. To remove moisture from the gas sample, the sample lines were run through refrigerated water $\left(4^{\circ} \mathrm{C}\right)$ that was automatically drained and through a column of $\mathrm{Mg}\left(\mathrm{ClO}_{4}\right)_{2}$. The environmental data for mean daytime $\mathrm{CO}_{2}$ concentrations, which were not significantly different among the temperature treatments, were $420 \mu \mathrm{mol} \cdot \mathrm{mol}^{-1}$ for the experimental period (Table 1).

\subsubsection{Measurements and Data Analysis}

Four seed per pot were sown and time for 50\% emergence (t50\%) was recorded when the two cotyledons appear above the soil surface in each pot as described by Fehr et al. [9]. Seed emergence rate (SER) was calculated as a reciprocal to $\mathrm{t} 50 \%$. The data were subjected to analysis of variance [25] with completely randomized design considering cultivars and temperature treatments as sources of variance. Replicated values for seed emergence data were analyzed using one-way ANOVA of the general linear model, PROC GLM, in SAS [25] to determine the effect of temperature on the measured parameters. Data were tested for differences among the treatments for the parameters measured using Fisher's protected least significant difference test at $P \leq 0.05$ and the standard errors of the means were calculated. To determine the best-fit equations between temperature and seed germination parameters, $\mathrm{R}^{2}$ was used. Graphical analysis was carried out using SigmaPlot 13.0 (Systat Software Inc., San Jose, CA).

\subsection{Validation Experiments}

\subsubsection{Outdoor Experiment Facility and Cultivars}

A series of short-term pot-culture experiments were conducted in outdoor conditions from 24 March to 22 July 2015 to generate data needed to validate the model. The same two cultivars, AG and PR that used in the first experiment were used in these experiments. The cultural aspects including soil and nutrient conditions were similar to those described in Experiment I. Five pots were used for each cultivar as replications. Four seed were seeded in each pot. The air temperature was recorded using a WatchDog sensor (B100, Spectrum Technologies, Inc., Plainfield, IL). The seed emergence, t50\%, as defined in Experiment 1, was recorded in all pots and treatments and SER was estimated from those measurements.

\subsubsection{Sunlit Controlled Environment Experiment and Cultivars}

This experiment was conducted in the SPAR units with similar management and cultural practices as described in Experiment I. In this experiment, we evaluated 64 soybean cultivars belonging to MG III, IV, and V that are commonly grown in the US Midsouth under three different day/night temperature treatments, low $-20^{\circ} \mathrm{C} / 12^{\circ} \mathrm{C}$, optimum $-30^{\circ} \mathrm{C} / 22^{\circ} \mathrm{C}$, and high $-40^{\circ} \mathrm{C} / 32^{\circ} \mathrm{C}$. The experiment was organized in a completely randomized design with two-factor interactions, three levels of temperature $\times 64$ cultivars, replicated three times such that each cultivar and temperature treatment appeared in each SPAR unit once, whereas replications represented as nine different SPAR units. Treated seeds of those 64 soybean cultivars were sown in 576 PVC plastic pots $(0.1 \mathrm{~m}$ diameter and $0.45 \mathrm{~m}$ 
tall), each filled with sandy soil and $0.250 \mathrm{~kg}$ of gravel at the bottom. The temperature treatments were imposed soon after sowing and continued until 20 days after sowing.

Four seed were seeded in each pot, and t50\% was recorded in each pot. Then, SER was calculated as described earlier. Two-way analysis (ANOVA) was performed on the replicated values of the measured parameters using the PROC GLM procedure in SAS [25] to determine the effect of temperature, cultivar, and their interaction. Post ANOVA means comparison was made using the least significant difference $(L S D=0.05)$. Models performance statistics were carried out as described by Loague and Green [26], Mitchell and Sheehy [27] Reddy et al. [28] and Reddy and Bonne [29].

\section{Result and Discussions}

\subsection{Quantifying and Modeling the Effect of Temperature on Seed Emergence}

The range of temperatures imposed in this study to generate the data needed for developing the relationships between temperature and $\mathrm{t} 50 \%$ and SGR represented the temperature variability of the current and projected future climatic conditions across global Soybean Belt. The analysis of variance revealed no significant differences between the two cultivars, for the parameters recorded, $\mathrm{t} 50 \%$ and SGR (Table 2). Therefore, quadratic functions best described the relationship between temperature and $\mathrm{t} 50 \%$ and SER for the pooled data (Figure 1).

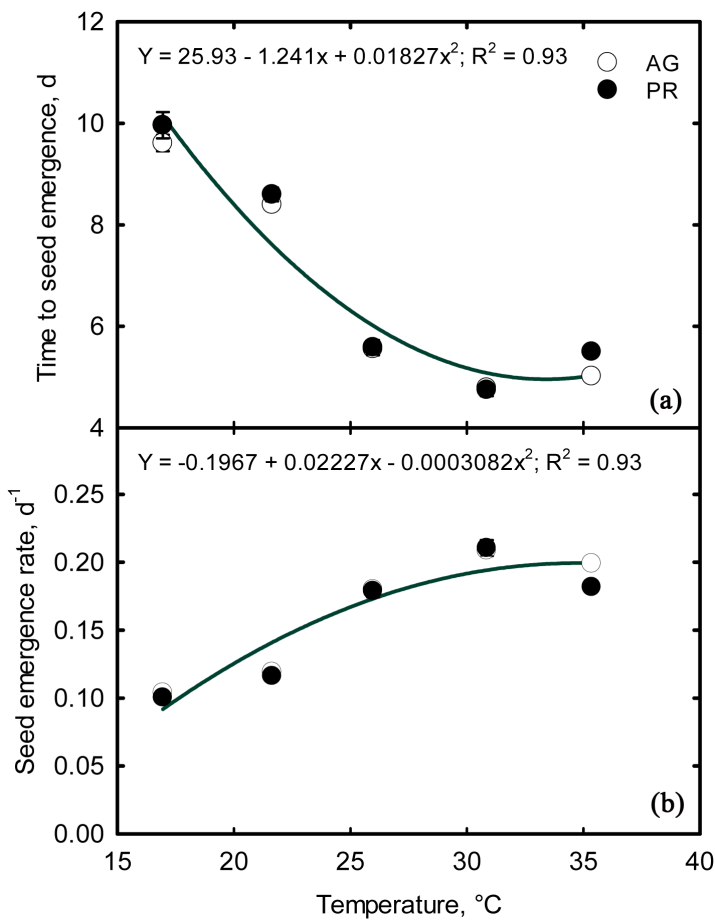

Figure 1. Temperature effects on soybean (a) time for $50 \%$ of seed emergence (t50\%) and (b) seed emergence rate (SER). Each data point is mean of nine replications, and standard errors are shown if the values are larger than the symbols. 
Table 2. Analysis of variation across temperatures, cultivars, and their interaction with soybean time for $50 \%$ seed emergence and emergence rate.

\begin{tabular}{cccc}
\hline Sources of variation & Temperature & $\begin{array}{c}\text { Cultivar } \\
P \text { Value }\end{array}$ & Temperature $\times$ Cultivar \\
\hline Time for $50 \%$ emergence & $<0.0001$ & 0.1117 & 0.5987 \\
Emergence rate & $<0.0001$ & 0.0748 & 0.0765 \\
\hline
\end{tabular}

Days to $50 \%$ seed emergence, t50\%, decreased with an increase in temperature and the SER increased with increase in temperature. The estimated temperature minimum for $\mathrm{SGR}$ was $10.6^{\circ} \mathrm{C}$, and the optimum was $36.67^{\circ} \mathrm{C}$. At the optimum temperature, it took five days to reach $\mathrm{t} 50 \%$ whereas at the lowest temperature imposed in this experiment $\left(\sim 16^{\circ} \mathrm{C}\right)$, it took almost double that time, 10.8 days (Figure 1). Similar quadratic responses were observed for cotton in response air and soil temperatures [14] and soybean in response to soil temperature [11]. Even though the estimated minimum temperature from this study was similar to the reported values [11], the optimum temperature observed in this study was higher by $5^{\circ} \mathrm{C}$ than the previous study. This could be due to improved heat tolerance in the recently released cultivars. [16] proposed Growing Degree Days Model (GDD) in predicting seed emergence in soybean with a base temperature of $50^{\circ} \mathrm{F}\left(10^{\circ} \mathrm{C}\right)$ and the growing degree days required for seed emergence was 90 GDDs from $50^{\circ} \mathrm{F}\left(32.22 \mathrm{GDD}\right.$ 's from $\left.10^{\circ} \mathrm{C}\right)$.

\subsection{Validation Experiments}

There were no differences between the cultivars for $t 50 \%$ seed emergence and SGR for a given seeding date (Table 3). However, differences for $\mathrm{t} 50 \%$ and SER were observed among seeding dates, as temperature conditions were different for each of those experimental periods in the first validation experiment. The temperatures ranged from $17.37^{\circ} \mathrm{C}$ to $31.9^{\circ} \mathrm{C}$ and which contributed to the observed variation in $\mathrm{t} 50 \%$ that ranged from 10.4 to 4.0 days for those temperature conditions, respectively.

In the second validation experiment with 64 cultivars from MG III, IV, and V, t50\% and SER varied among the temperatures (Table 4). Cultivars did not differ within a given temperature treatment. On average, the soybean cultivars took 9.6 days at $20^{\circ} \mathrm{C} / 12^{\circ} \mathrm{C}, 5.3$ days at $30^{\circ} \mathrm{C} / 22^{\circ} \mathrm{C}$, and 4.3 days at $40^{\circ} \mathrm{C} / 32^{\circ} \mathrm{C}$ (Table 4 ).

\subsection{Model Comparisons}

The quadratic model developed in this study for the relationship between temperature and soybean seed emergence was compared with the published GDD model [16]. The performance of the models for SER was tested on 17-time series experiments sown outdoors with the same cultivars used in model development and a sunlit controlled environment experiment with three different day/night temperature treatments with 64 cultivars [27]. First, we used regression parameters, $\mathrm{R}^{2}$, slopes, and intercepts, and mean sum square errors (MMSE) of the 
Table 3. Time for 50\% emergence and emergence rate of two soybean cultivars, Asgrow AG5332 (AG) and Progeny P5332 RY (PR) seeded at different periods with sowing dates.

\begin{tabular}{|c|c|c|c|c|c|}
\hline \multirow{2}{*}{ Panting date } & \multirow{2}{*}{$\begin{array}{c}\text { Average air } \\
\text { temperature, }{ }^{\circ} \mathrm{C}\end{array}$} & \multicolumn{2}{|c|}{ Time to $50 \%$ emergence, $\mathrm{d}$} & \multicolumn{2}{|c|}{ Seed emergence rate, $\mathrm{d}^{-}$} \\
\hline & & AG & $\mathrm{PR}$ & AG & $\mathrm{PR}$ \\
\hline 24 March & 17.37 & 10.4 & 10.5 & 0.10 & 0.10 \\
\hline 30 March & 19.84 & 8.1 & 8.4 & 0.12 & 0.12 \\
\hline 04 April & 19.58 & 8.4 & 8.5 & 0.12 & 0.12 \\
\hline 10 April & 21.27 & 6.2 & 6.7 & 0.16 & 0.15 \\
\hline 23 April & 22.83 & 7.4 & 7.5 & 0.14 & 0.13 \\
\hline 30 April & 24.35 & 6.1 & 6.2 & 0.17 & 0.16 \\
\hline 10 May & 24.79 & 6.2 & 5.9 & 0.16 & 0.17 \\
\hline 20 May & 25.07 & 6.4 & 6.4 & 0.16 & 0.16 \\
\hline 30 May & 24.81 & 6.2 & 6.4 & 0.16 & 0.16 \\
\hline 12 June & 30.39 & 5.0 & 5.3 & 0.20 & 0.19 \\
\hline 18 June & 31.9 & 4.0 & 4.3 & 0.25 & 0.24 \\
\hline 23 June & 30.51 & 4.3 & 4.7 & 0.24 & 0.22 \\
\hline 29 June & 27.71 & 5.1 & 5.3 & 0.20 & 0.19 \\
\hline 04 July & 28.74 & 4.3 & 4.6 & 0.23 & 0.22 \\
\hline 09 July & 28.82 & 4.1 & 4.2 & 0.24 & 0.24 \\
\hline 14 July & 29.62 & 5.2 & 5.3 & 0.19 & 0.19 \\
\hline 22 July & 28.61 & 4.4 & 4.3 & 0.23 & 0.23 \\
\hline Temperature & $D_{\mathrm{N}}$ & \multicolumn{2}{|c|}{$<0.0001$} & \multicolumn{2}{|c|}{$<0.0001$} \\
\hline Cultivars & $P$ value & \multicolumn{2}{|c|}{0.0725} & \multicolumn{2}{|c|}{0.4221} \\
\hline
\end{tabular}

Table 4. Soybean cultivars, Maturity Group (MG) and time for $50 \%$ seed emergence ( $\mathrm{t} 50 \%)$ and seed emergence rate (SER) for 64 soybean cultivars grown at low $\left(\mathrm{LT}-20^{\circ} \mathrm{C} / 12^{\circ} \mathrm{C}\right.$ ), optimum $\left(\mathrm{OT}-30^{\circ} \mathrm{C} / 22^{\circ} \mathrm{C}\right)$, and high $\left(\mathrm{HT}-40^{\circ} \mathrm{C} / 32^{\circ} \mathrm{C}\right)$ temperature conditions.

\begin{tabular}{|c|c|c|c|c|c|c|c|c|}
\hline \multirow[t]{2}{*}{ Company } & \multirow[t]{2}{*}{ Cultivar } & \multirow{2}{*}{$\begin{array}{l}\text { Maturity } \\
\text { group }\end{array}$} & \multicolumn{3}{|c|}{$\begin{array}{l}\text { Time for } 50 \% \\
\text { emergence ( } \mathrm{t} 50 \%) \text {, days }\end{array}$} & \multicolumn{3}{|c|}{$\begin{array}{l}\text { Seed emergence } \\
\text { rate, } \mathrm{d}^{-1}\end{array}$} \\
\hline & & & LT & OT & HT & LT & OT & HT \\
\hline Dyna-Gro Seed & $32 \mathrm{y} 39$ & III & 10.3 & 5.3 & 4.3 & 0.10 & 0.19 & 0.23 \\
\hline Mycogen Seeds & $5 \mathrm{~N} 393 \mathrm{R} 2$ & III & 8.7 & 5.3 & 4.3 & 0.12 & 0.19 & 0.23 \\
\hline Syngenta United States & S39-T3 & III & 10.7 & 5.3 & 4.0 & 0.09 & 0.19 & 0.25 \\
\hline Syngenta United States & S39-C4 & III & 9.3 & 5.3 & 4.7 & 0.11 & 0.19 & 0.21 \\
\hline REV Brand Seeds & $38 \mathrm{R} 10$ & III & 8.7 & 5.0 & 4.3 & 0.12 & 0.20 & 0.23 \\
\hline $\begin{array}{l}\text { Go Soy Genetics } \\
\text { Optimized }\end{array}$ & IREANE & IV & 9.0 & 6.0 & 4.3 & 0.11 & 0.17 & 0.23 \\
\hline $\begin{array}{c}\text { Go Soy Genetics } \\
\text { Optimized }\end{array}$ & $483 \mathrm{C}$ & IV & 8.7 & 5.3 & 5.0 & 0.12 & 0.19 & 0.20 \\
\hline
\end{tabular}


F. A. Alsajri et al.

\section{Continued}

\begin{tabular}{|c|c|c|c|c|c|c|c|c|}
\hline UniSouth Genetics Inc. & ELLIS & IV & 9.0 & 5.0 & 4.3 & 0.11 & 0.20 & 0.23 \\
\hline REV Brand Seeds & $48 \mathrm{~L} 63$ & IV & 10.0 & 5.3 & 4.7 & 0.10 & 0.19 & 0.21 \\
\hline $\begin{array}{c}\text { Delta Grow } \\
\text { Seeds Com. Inc. }\end{array}$ & DG4781LL & IV & 9.3 & 5.7 & 4.7 & 0.11 & 0.18 & 0.21 \\
\hline $\begin{array}{c}\text { Go Soy Genetics } \\
\text { Optimized }\end{array}$ & $4714 \mathrm{LL}$ & IV & 9.3 & 5.0 & 5.0 & 0.11 & 0.20 & 0.20 \\
\hline Progeny Ag Products & P 4247 LL & IV & 9.7 & 5.0 & 4.3 & 0.10 & 0.20 & 0.23 \\
\hline Bayer Credenz & CZ $4044 \mathrm{LL}$ & IV & 10.0 & 5.3 & 4.0 & 0.10 & 0.19 & 0.25 \\
\hline Dyna-Gro Seeds & S49LL34 & IV & 8.7 & 5.3 & 4.0 & 0.12 & 0.19 & 0.25 \\
\hline DoPont Pioneer & P41T33R & IV & 9.3 & 5.3 & 4.0 & 0.11 & 0.19 & 0.25 \\
\hline $\begin{array}{l}\text { Delta Grow Seeds } \\
\text { Com. Inc. }\end{array}$ & DG 4680RR2 & IV & 9.3 & 5.3 & 4.0 & 0.11 & 0.19 & 0.25 \\
\hline REV Brand Seeds & $45 \mathrm{~A} 46$ & IV & 10.3 & 5.7 & 4.3 & 0.10 & 0.18 & 0.23 \\
\hline Mycogen Seeds & $5 \mathrm{~N} 424 \mathrm{R} 2$ & IV & 10.0 & 5.0 & 4.7 & 0.10 & 0.20 & 0.21 \\
\hline Dyna-Gro Seed & 31RY45 & IV & 10.7 & 5.3 & 4.0 & 0.09 & 0.19 & 0.25 \\
\hline AGSouth Genetics & GS45R216 & IV & 9.3 & 5.7 & 4.0 & 0.11 & 0.18 & 0.25 \\
\hline Asgrow & AG4632 & IV & 10.0 & 5.3 & 4.3 & 0.10 & 0.19 & 0.23 \\
\hline Progeny Ag Products & P 4588RY & IV & 9.7 & 5.3 & 4.0 & 0.10 & 0.19 & 0.25 \\
\hline Syngenta United States & S45-W9 & IV & 9.3 & 5.3 & 4.0 & 0.11 & 0.19 & 0.25 \\
\hline Bayer Credenz & CZ $4181 \mathrm{RY}$ & IV & 8.7 & 5.7 & 4.0 & 0.12 & 0.18 & 0.25 \\
\hline $\begin{array}{l}\text { Delta Grow Seed } \\
\text { Com. Inc. }\end{array}$ & DG 4825RR2/STS & IV & 9.0 & 5.3 & 4.7 & 0.11 & 0.19 & 0.21 \\
\hline DuPont Pioneer & P47T36R & IV & 9.7 & 5.0 & 4.3 & 0.10 & 0.20 & 0.23 \\
\hline Syngenta United States & S47-K5 & IV & 9.3 & 5.3 & 4.3 & 0.11 & 0.19 & 0.23 \\
\hline AGSouth Genetics & GS47R216 & IV & 9.3 & 5.3 & 4.0 & 0.11 & 0.19 & 0.25 \\
\hline Armor Seeds & AR4705 & IV & 10.3 & 6.0 & 4.7 & 0.10 & 0.17 & 0.21 \\
\hline Mycogen Seed & 5N490R2 & IV & 9.7 & 5.3 & 4.3 & 0.10 & 0.19 & 0.23 \\
\hline REV Brand Seeds & $48 \mathrm{~A} 26$ & IV & 10.3 & 5.7 & 4.0 & 0.10 & 0.18 & 0.25 \\
\hline Progeny Ag Products & P 4757 RY & IV & 10.0 & 5.3 & 4.3 & 0.10 & 0.19 & 0.23 \\
\hline Dyna-Gro Seeds & S48RS53 & IV & 9.7 & 5.3 & 4.7 & 0.10 & 0.19 & 0.21 \\
\hline $\begin{array}{c}\text { Go Soy Genetics } \\
\text { Optimized }\end{array}$ & 4814GTS & IV & 9.7 & 5.0 & 4.3 & 0.10 & 0.20 & 0.23 \\
\hline $\begin{array}{c}\text { Croplan Win Field } \\
\text { United }\end{array}$ & $\mathrm{R} 2 \mathrm{C} 4775$ & IV & 10.3 & 5.7 & 4.0 & 0.10 & 0.18 & 0.25 \\
\hline Bayer Credenz & CZ $4898 \mathrm{RY}$ & IV & 9.7 & 5.3 & 4.3 & 0.10 & 0.19 & 0.23 \\
\hline Dixie Belle & DB 4911 & IV & 8.3 & 5.3 & 4.0 & 0.12 & 0.19 & 0.25 \\
\hline Great Heart Seed Com. & GT-476CR2 & IV & 10.3 & 5.3 & 4.0 & 0.10 & 0.19 & 0.25 \\
\hline
\end{tabular}




\section{Continued}

\begin{tabular}{|c|c|c|c|c|c|c|c|c|}
\hline NC State University & PI 471938 & IV & 10.3 & 5.0 & 4.0 & 0.10 & 0.20 & 0.25 \\
\hline University of Missouri & $\mathrm{R} 01-416 \mathrm{~F}$ & IV & 9.7 & 5.0 & 4.0 & 0.10 & 0.20 & 0.25 \\
\hline Asgrow & AG5332 & $\mathrm{V}$ & 9.7 & 5.7 & 4.3 & 0.10 & 0.18 & 0.23 \\
\hline Progeny & P 5333 RY & $\mathrm{V}$ & 9.3 & 5.0 & 4.7 & 0.11 & 0.20 & 0.21 \\
\hline USDA-ARS & JTN-5110 & $\mathrm{V}$ & 9.0 & 5.0 & 4.3 & 0.11 & 0.20 & 0.23 \\
\hline $\begin{array}{l}\text { GoSoy Genetics } \\
\text { Optimized }\end{array}$ & LELAND & $\mathrm{V}$ & 9.7 & 5.7 & 4.7 & 0.10 & 0.18 & 0.21 \\
\hline $\begin{array}{c}\text { Delta Grow } \\
\text { Seeds Com. Inc. }\end{array}$ & DG 5067 LL & $\mathrm{V}$ & 9.7 & 5.3 & 4.3 & 0.10 & 0.19 & 0.23 \\
\hline $\begin{array}{l}\text { Go Soy Genetics } \\
\text { Optimized }\end{array}$ & $5115 \mathrm{LL}$ & $\mathrm{V}$ & 9.3 & 5.3 & 4.7 & 0.11 & 0.19 & 0.21 \\
\hline Dyna-Gro Seed & S55LS75 & $\mathrm{V}$ & 9.7 & 5.7 & 4.3 & 0.10 & 0.18 & 0.23 \\
\hline Bayer Credenz & CZ 5242 LL & $\mathrm{V}$ & 9.0 & 5.7 & 4.3 & 0.11 & 0.18 & 0.23 \\
\hline Bayer Credenz & CZ 5225 LL & $\mathrm{V}$ & 10.7 & 5.0 & 4.0 & 0.09 & 0.20 & 0.25 \\
\hline $\begin{array}{l}\text { Delta Grow Seeds } \\
\text { Com. Inc. }\end{array}$ & DG 5170 RR2/STS & $\mathrm{V}$ & 10.7 & 5.3 & 4.0 & 0.09 & 0.19 & 0.25 \\
\hline REV Brand Seeds & $51 \mathrm{~A} 56$ & $\mathrm{~V}$ & 9.7 & 5.0 & 4.3 & 0.10 & 0.20 & 0.23 \\
\hline DuPont Pioneer & P52T50R & $\mathrm{V}$ & 9.3 & 5.3 & 4.0 & 0.11 & 0.19 & 0.25 \\
\hline Syngenta United States & S55-Q3 & $\mathrm{V}$ & 9.3 & 5.3 & 4.3 & 0.11 & 0.19 & 0.23 \\
\hline Syngenta United States & S56-M8 & $\mathrm{V}$ & 8.7 & 5.3 & 4.0 & 0.12 & 0.19 & 0.25 \\
\hline $\begin{array}{l}\text { Go Soy Genetics } \\
\text { Optimized }\end{array}$ & $5214 \mathrm{GTS}$ & $\mathrm{V}$ & 10.3 & 5.3 & 4.3 & 0.10 & 0.19 & 0.23 \\
\hline Armor & $55-\mathrm{R} 68$ & $\mathrm{~V}$ & 9.3 & 5.0 & 4.0 & 0.11 & 0.20 & 0.25 \\
\hline Progeny Ag Products & P 5226 RYS & $\mathrm{V}$ & 8.7 & 5.7 & 5.0 & 0.12 & 0.18 & 0.20 \\
\hline Mycogen Seeds & 5N523R2 & $\mathrm{V}$ & 9.7 & 6.0 & 4.7 & 0.10 & 0.17 & 0.21 \\
\hline Dyna-Gro Seed & S56RY84 & $\mathrm{V}$ & 10.7 & 5.3 & 4.3 & 0.09 & 0.19 & 0.23 \\
\hline $\begin{array}{c}\text { Croplan Win Field } \\
\text { United }\end{array}$ & R2C5225S & $\mathrm{V}$ & 9.3 & 5.0 & 4.3 & 0.11 & 0.20 & 0.23 \\
\hline Bayer Credenz & CZ $5375 \mathrm{RY}$ & $\mathrm{V}$ & 9.7 & 5.7 & 4.3 & 0.10 & 0.18 & 0.23 \\
\hline REV Brand Seeds & $57 \mathrm{R} 21$ & $\mathrm{~V}$ & 10.0 & 5.3 & 4.7 & 0.10 & 0.19 & 0.21 \\
\hline Syngenta United States & S58-Z4 & $\mathrm{V}$ & 9.7 & 5.0 & 4.0 & 0.10 & 0.20 & 0.25 \\
\hline Dyna-Gro Seed & S57RY26 & $\mathrm{V}$ & 9.7 & 5.3 & 4.0 & 0.10 & 0.19 & 0.25 \\
\hline Mean & & & 9.6 & 5.3 & 4.3 & 0.10 & 0.19 & 0.23 \\
\hline Temperature & $P$ Value & & & $<0.0001$ & & & $<0.0001$ & \\
\hline Cultivars & & & & 0.0613 & & & 0.5887 & \\
\hline
\end{tabular}


models of observed and predicted seed emergence data to test the performance of the models. The model with $\mathrm{R}^{2}$ and slope values closer to one, intercept values closer to zero, and the lowest MMSE values were considered the better model in predicting seed emergence rate in soybean. For MMSE, the following steps were used to estimate the values.

The mean of the sum of square error (MMSE):

$$
\begin{gathered}
\text { DIF }=(\text { Observed }- \text { predicted })^{2} \\
\text { MDIF }=(\Sigma \mathrm{DIF}) / n_{i} \\
\text { MMSE }=(\Sigma \mathrm{MDIF}) / n_{i}
\end{gathered}
$$

where DIF is the difference between observed and predicted values, MDIF is the mean DIF, and $n_{i}$ is the number of observations in the validation experiment. Based on this, the model with the smallest MMSE was considered as the best model. This was necessary because the different experimental conditions were sampled on different validation experiments. Based on these model validation metrics, the QM performed slightly better the GDD model for soybean seed emergence over a wide range of environmental conditions, planting dates, and cultivars. Both the models, however, have higher $\mathrm{R}^{2}$ when regressed between observed and predicted days for seed emergence (Figure 2).

Since evaluations of the accuracy of models with observed data is not always straightforward [26] [27] [28] [29], we used an alternative method for determining model accuracy proposed by Loague et al. [26] known as "Envelop of Acceptable Precision (EAP)" and the portion of points (Deviations of the model from observed values) that are within a predetermined allowable error. Figure 3 illustrates the scatter plot of deviations set to $\pm 10 \%$ of the observed values of t50\% for both models. With a predetermined allowable error of $\pm 10 \%$ of the observed value for $\mathrm{t} 50 \%$, the envelopes of acceptable precision defined by the straight lines originating from the plots of these positive and negative points (Figure 3), $60 \%$ of predicted values of the quadratic model were within the $10 \%$ envelop compared to $40 \%$ for the GDD.

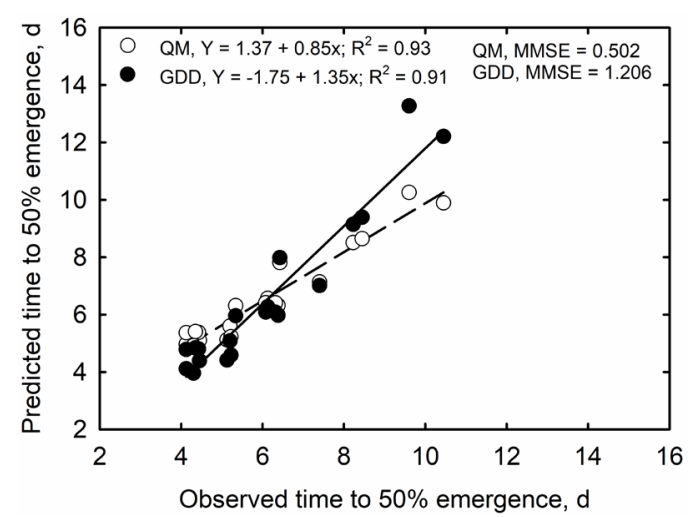

Figure 2. Comparison of observed and simulated days to time to $50 \%$ seed emergence $(\mathrm{t} 50 \%)$ of the growing degree day (GDD) and quadratic (QM) models for soybean seed emergence across a wide range of genetic, experimental, and environmental conditions. 


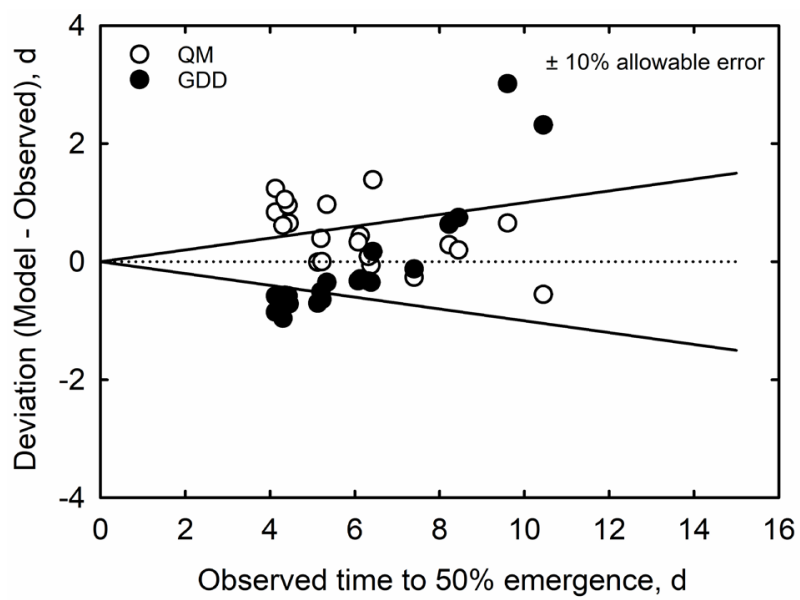

Figure 3. The plot of deviations of observed values of quadratic (QM) and growing degree day (GDD) models for soybean time for $50 \%$ seed emergence.

\section{Summary and Conclusions}

Soybean seed emergence rate increased with increase in temperature. There were no cultivar differences for SER at a set temperature conditions. A quadratic model best described the relationship between temperature and soybean seed emergence rate. Based on this model, the estimated base and optimum temperatures for soybean seed emergence were $10.6^{\circ} \mathrm{C}$ and $36.7^{\circ} \mathrm{C}$, respectively. The QM presented in this study performed better than the GDD model for seed emergence rate across a wide range of environmental conditions and among several cultivars belonging to soybean maturity Groups III to V. The QM reduced the overall variability by $58 \%$ and improved model performance by $10 \%$ over the GDD model in predicting SGR across a wide range of experimental and environmental conditions, planting dates, and cultivars. The temperature-SER dependent functional relationship could improve the functionality of many soybean models (FAO, AQUACROP, DSSAT, APSIM, and MONICA; [30] [31]), for field management, and in policy applications. Also, QM for SER has been used in a soybean blog so that the producers could use this model in predicting seedling emergence under optimal moisture conditions under a wide geographical area and sowing dates [32]. However, other factors such as soil moisture, oxygen, flooding, and seed depth, are needed to be able to predict soybean seed emergence more accurately.

\section{Acknowledgements}

We thank David Brand for technical assistance and graduate students of the Environmental Plant Physiology Lab at Mississippi State University for their support during data collection. This article is a contribution from the Department of Plant and Soil Sciences, Mississippi State University, Mississippi Agricultural, and Forestry Experiment Station. This research was partially funded by the Mississippi Soybean Promotion Board and National Institute of Food and Agriculture, NIFA and 2016-34263-25763 and MIS 043040. 


\section{Conflicts of Interest}

The authors declare no conflicts of interest regarding the publication of this paper.

\section{References}

[1] Brandelero, E.M., Adami, P.F., Modolo, A.J., Baesso, M.M. and Fabian, A.J. (2015) Seeder Performance under Different Speeds and Its Relation to Soybean Cultivars Yield. Journal of Agronomy, 14, 139-145. https://doi.org/10.3923/ja.2015.139.145

[2] Dias, M.A.N., Pinto, T.L.F., Mondo, V.H.V., Cicero, S.M. and Pedrini, L.G. (2011) Direct Effects of Soybean Seed Vigor on Weed Competition. Journal of Seed Science, 33, 346-351.

[3] Egli, D.B. (1993) Relationship of Uniformity of Soybean Seedling Emergence to Yield. Journal of Seed Technology, 17, 22-28. http://www.jstor.org/stable/23432764

[4] Kolchinski, E.M., Schuch, L.O.B. and Peske, S.T. (2006) Early Growth of Soybean Plants in Relation to Seeds Vigor. Revista Brasileira de Agrociência, 12, 163-166.

[5] Kolchinski, E.M., Schuch, L.O.B. and Peske, S.T. (2005) Seeds Vigor and Intra-Specific Competition in Soybean. Ciência Rural, 35, 1248-1256.

https://doi.org/10.1590/S0103-84782005000600004

[6] Mondo, V.H.V., Dias, M.A.N., Cicero, S.M. (2015) Maize Seed Vigor and Its Effects on Crop Cultivation Cycle. Revista de Agricultura, 90, 168-178.

[7] Schuch, L.O.B., Kolchinski, E.M. and Finatto, J.A. (2009) Seed Physiological Quality and Individual Plants Performance in Soybean. Journal of Seed Science, 31,144-149.

[8] Vanzolini, S., Carvalho, N.M. (2002) Effects of Soybean Seed Vigor on Field Plant Performance. Journal of Seed Science, 24, 33-41.

[9] Fehr, W.R., Caviness, C.E. Burmood, D.T. and Pennington, J.S. (1971) Stage of Development Descriptions for Soybeans, Glycine max (1.) Merrill. Crop Science, 111, 929-931. https://doi.org/10.2135/cropsci1971.0011183X001100060051x

[10] Edwards Jr., C.J. and Hartwig, E.E. (1971) Effect of Seed Size upon Rate of Germination in Soybeans. Agronomy Journal, 63, 449-450. https://doi.org/10.2134/agronj1971.00021962006300030024x

[11] Hatfield, J.L. and Egli, D.B. (1974) Effect of Temperature on the Rate of Soybean Hypocotyl Elongation and Field Emergence. Crop Science, 14, 423-426. https://doi.org/10.2135/cropsci1974.0011183X001400030025x

[12] Hopper, N.W., Overholt, J.R. and Martin, J.R. (1979) Effect of Cultivar, Temperature and Seed Size on the Germination and Emergence of Soya Beans (Glycine max (L.) Merr.). Annals of Botany, 44, 301-308. https://doi.org/10.1093/oxfordjournals.aob.a085733

[13] Benjamin, L.R. (1990) Variation in Time of Seedling Emergence within Populations: A Feature That Determines Individual Growth and Development. Advances in Agronomy, 44, 1-25. https://doi.org/10.1016/S0065-2113(08)60816-0

[14] Reddy, K.R., Brand, D., Wijewardana, C. and Gao, W. (2017) Temperature Effects on Cotton Seedling Emergence, Growth, and Development. Agronomy Journal, 109, 1379-1387. https://doi.org/10.2134/agronj2016.07.0439

[15] Wijewardana, C., Hock, M., Henry, B. and Reddy, K.R. (2015) Screening Corn Hybrids for Cold Tolerance Using Morphological Traits for Early-Season Seeding. Crop Science, 55, 851-867. https://doi.org/10.2135/cropsci2014.07.0487

[16] Castiel, S. (2010) Soybean Physiology: How Well Do You Know Soybeans? Purdue 
University. Soybean Station. http://www.soybeanstation.org

[17] Wang, J.Y. (1960) A Critique of the Heat Unit Approach to Plant Response Studies. Ecology, 41, 785-790. https://doi.org/10.2307/1931815

[18] Reddy, K.R., Hodges, H.F. and McKinion, J.M. (1993) A Temperature Model for Cotton Phenology. Biotronics, 22, 47-59.

[19] Reddy, K.R., Hodges, H.F. and McKinion, J.M. (1997) Crop Modeling and Applications: A Cotton Example. Advances in Agronomy, 59, 225-290. https://doi.org/10.1016/S0065-2113(08)60056-5

[20] McMaster, G.S. and Wilhelm, W.W. (1997) Growing Degree-Days: One Equation, Two Interpretations. Agricultural and Forest Meteorology, 87, 291-300. https://doi.org/10.1016/S0168-1923(97)00027-0

[21] Reddy, K.R., Hodges, H.F., Read, J.J., McKinion, J.M., Baker, J.T., Tarpley, L. and Reddy, V.R. (2001) Soil-Plant-Atmosphere-Research (SPAR) Facility: A Tool for Plant Research and Modeling. Biotronics, 30, 27-50.

[22] Murray, F.W. (1967) On the Computation of Saturation Vapor Pressure. Journal of Applied Meteorology, 6, 203-204. https://doi.org/10.1175/1520-0450(1967)006<0203:OTCOSV >2.0.CO;2

[23] McKinion, J.M. and Hodges, H.F. (1985) Automated System for Measurement of Evapotranspiration from Closed Environmental Growth Chambers. Transactions of the ASAE, 28, 1825-1828. https://doi.org/10.13031/2013.32526

[24] Hoagland, D.R. and Arnon, D.I. (1950) The Water-Culture Method for Growing Plants without Soil. The College of Agriculture University of California, Berkeley.

[25] SAS Institute (2011) SAS Guide to Macro Processing. Vol. 11, SAS Inst., Cary.

[26] Loague, K. and Green, R.E. (1991) Statistical and Graphical Methods for Evaluating Solute Transport Models: Overview and Applications. Journal of Contaminant Hydrology, 7, 51-73. https://doi.org/10.1016/0169-7722(91)90038-3

[27] Mitchell, P.L. and Sheehy, J.E. (1997) Comparison of Predictions and Observations to Assess Model Performance: A Method of Empirical Validation. In: Kropff, M.J., Teng, P.S., Aggarwal, P.K., Bouma, J., Bouman, B.A.M., Jones, K.W. and van Laar, H.H., Eds., Applications of Systems Approaches at the Field Level System to Cotton Crop Management, Volume 2, Kluwer Academic Publishers, Dordrecht, 55-65. https://doi.org/10.1007/978-94-017-0754-1_31

[28] Reddy, K.R., Boone, M.L., Reddy, A.R., Hodges, H.E., Turner, S.B. and McKinion, J.M. (1995) Developing and Validating a Model for a Plant Growth Regulator. Agronomy Journal, 87, 1100-1105. https://doi.org/10.2134/agronj1995.00021962008700060011x

[29] Reddy, K.R. and Boone, M.L. (2002) Modeling and Validating Cotton Leaf Area Development and Stem Elongation. Acta Horticulturae, 593, 193-199. https://doi.org/10.17660/ActaHortic.2002.593.25

[30] Battisti, R.A., Paulo, C., Sentelhas, A. and Boote, K.J. (2017) Inter-Comparison of Performance of Soybean Crop Simulation Models and Their Ensemble in Southern Brazil. Field Crops Research, 200, 28-37. https://doi.org/10.1016/j.fcr.2016.10.004

[31] Acock, B., Pachepsky, Y.A., Mironenko, E.V., Whisler, F.D. and Reddy, V.R. (1999) GUICS: A Generic User Interface for On-Farm Crop Simulations. Agronomy Journal, 91, 657-665. https://doi.org/10.2134/agronj1999.914657x

[32] Heatherly, L. (2015) Temperature and Soybean Emergence. Mississippi Soybean Promotion Board (MSPB) Blog.

https://mssoy.org/blog/temperature-and-soybean-emergence 